\section{Technological glasnost}

Zhores A. Medvedev

Science Policy in the Sovlet Union. By Stephen Fortescue. Routledge: 1990:

Pp.230. £35.

Science and the Soviet Social Order. Edited by Loren R. Graham. Harvard University Press: 1990. Pp.443. \$35.00, £27.95.

THE Soviet Union, as is made clear in Science Policy in the Soviet Union and Science and the Soviet Social Order, has half the scientists and engineers in the world, a fact which has been a source of pride for Soviet leaders. "But why" asks Harley Balzer in the second of these volumes, "with all that skilled personnel, does the Soviet economic system perform so poorly? Is the problem with the system or the people?" In the 1920s, 1930s and 1940 s it was apparently the system that was mainly responsible. Now that engineering or academic qualifications are essential for recruitment and promotion of members of political elite and top management of the Soviet Union and in all its republics the system cannot be so clearly separated from the people. For decades the system used to suppress and punish independent individual initiative and to create the most restrictive environment for technical research and artistic creativity while simultaneously improving opportunities for advanced education. This led to an overproduction of intellectuals who in general do not occupy the same middleclass position as in less ideologically motivated and more technocratic western societies.

In Science Policy in the Soviet Union, Stephen Fortescue reviews the general structure of Soviet scientific establishment up to 1989. The book contains many useful tables and data on the numbers of scientists who work in the Soviet Academy of Sciences and its regional branches, in union-republic academies, in the universities and other institutes of higher education, and in applied ministerial research networks. In addition, there is copious information about vertical interactions and subordination in science, from the level of Politburo, ministers, presidiums, directors, academic councils, heads of laboratories or chairmen of the departments. It gives a comprehensive picture of how financial funds move through the numerous links from the budget to the individuals and details how scientists receive their academic degrees and other credentials. But it does not attempt to discover why this enormous and well organized hierarchical pyrainid made of several million people produces so little high-quality research and so few technological breakthroughs.

Science and the Soviet Social Order is a product of many discussions sponsored by the Russian Research Center at Harvard University. It provides a very fresh and innovative analysis of the interaction between science and the political system. It tries not only to explain the peculiarities of the Soviet system which wanted to create its own separate Soviet science based on principles of dialectic materialism and marxist philosophy, but also to explain the failure to achieve this. The view emerges that, by putting the political leadership in charge of science and technology, the Soviet system was sometimes very effective in concentrating efforts for high-priority projects like nuclear projects and space exploration. (Even here, the names of the leading scientists and engineers

\section{IMAGE \\ UNAVAILABLE FOR COPYRIGHT REASONS}

Seat of Soviet science - Academy of Sciences in Moscow during the 1940s.

were kept secret and most of the credit for success was taken by the party leadership.) At the same time it also stimulated numerous pseudoscientific trends, for example, in human genetics as described by Mark Adams in his excellent essay on the Soviet nature-nurture debates. A very new and highly convincing perspective in explaining the backwardness of the Soviet R\&D system is given in the first part of Loren Graham's collection in two well written essays saturated with ideas; by Frederick Starr (new communications technologies and civil society) and by Seymour Goodman (information technologies and the citizen). The authors have produced a very convincing and brilliantly presented analysis arguing "that autocratic and authoritarian regimes onesidedly develop vertical communication links, while democratic societies require elaborate horizontal networks as well as vertical ones". They also show that the tsarist regime which monopolized the printing facilities and introduced censorship and state control for all forms of communication started the same trend which later the communist regime developed to perfection.

In the postwar Soviet Union from Stalin to Gorbachev, successive governments developed a very elaborate legislation to prevent or to control all forms of direct horizontal communication between individuals, groups, institutions, factories and administrative units. The central governmental and political bureaucracy always had to be involved even if this meant the continuing growth of all the structures of central apparatus. This compulsory use of vertical communications even for trivial matters inevitably delayed solutions, reduced diversity and put the Soviet Union well behind the west in all forms of communication and economic development. It was not a political revolt which finally eroded the power of the party bureaucracy, but the information technology which governments were not able to control. Short-wave radios, tapes, video, copiers, fax machines and computers created the technological glasnost which made information a real power. In every single case the Soviet government tried to control the horizontal lines of communication, at first by promoting loudspeakers instead of radios, then producing limited-wavelength radios, making Soviet-made videos incompatible with western models, by the introduction of a single gateway for all computerized data entering the Soviet Union and by making the use of modems forbidden for individual owners of personal computers and by banning the sale of copiers. The main task of the KGB during the first five years of perestroika became the restriction and control of the proliferation of communication technologies. But the $\mathrm{KGB}$ was losing the battle.

In 1989 when these papers were written, the authors predicted the inevitable failure of systems in which vertical lines of communication are dominant, but they did not know how long it would take. In fact, this failure happened much sooner than they ever expected. It was swift and dramatic in eastern Europe, but complex and painful in the Soviet Union. The abolition of censorship, the legalization of copiers and computer printers for individual use and the democratization of local elections happened nearly at once during late spring and summer of 1990 and suddenly reduced the power of central government. Without capability to control the existing developed horizontal links in science, economy and even trade, the imperial centralized structure started to fall apart. The government lost its ability to shape society, as predicted by F. Starr. But his expectation that the society instead will start to shape the government is yet to be fulfilled. Soviet society, so complex in its ethnic, cultural and political structure, is now moving more towards anarchy than to a new better and more advanced social order.

Zhores A. Medvedev is at the National Institute for Medical Research, Mill Hill, London NW7 1AA, UK. 